\title{
Article
}

http://dx.doi.org/10.11646/phytotaxa.174.5.4

\section{A new subspecies of Crocus pestalozzae (Iridaceae) from Turkey}

\author{
SIRRI YÜZBAȘIOĞLU ${ }^{1} \&$ NERIMAN ÖZHATAY ${ }^{1}$ \\ ${ }^{1}$ Department of Pharmaceutical Botany, Faculty of Pharmacy, İstanbul University, 34116, İstanbul, Turkey; E-mail: yuzbasis@istanbul. \\ edu.tr
}

\begin{abstract}
C. pestalozzae subsp. violaceus is described as a new subspecies from northwest Anatolia. The new taxa differs from subsp. pestalozzae by its flower colour, leaf and flower size, kartotype, habitat and growing elevation. Diagnostic characters, a full description, and detailed illustrations are presented. Also photograps of metephase plate, karyotypes and idiograms of two subsp. of C. pestalozzae are given. The geographical distribution of the subspecies is mapped. IUCN threatened category and observations on the population are noted.
\end{abstract}

Key words: Crocus, endemic, karyotype, taxonomy, Turkey

\section{Introduction}

The genus Crocus Linnaeus (1753: 36) occurs in the Mediterranean region and the drier floristic area to the east of the Mediterranean known as the Irano-Turanian region (Mathew 1982) and consists currently of about 129 recognized species (Erol et al. 2012, Harpke et al. 2013, Kerndorrf et al. 2013a, 2013b, 2013c, Peruzzi \& Carta 2011, Peruzzi et al. 2013, Y1ldirım \& Erol 2013). Turkey is an especially rich country in terms of Crocus species: Mathew (1984) listed 31 species [C. tournefortii Gay (1831:320) is not included] from Turkey. Later, Mathew (1988) added one subspecies. Four more species and two subspecies were added by Mathew (2000), and, as a result of more recent publications, the number of Crocus taxa in Turkey reached 119 (73 species) (Erol et al. 2012, Yüzbaş1oğlu 2012, Candan \& Özhatay 2013, Harpke et al. 2013, Kerndorrf et al. 2013a, 2013b, 2013c, Ruksans 2013, Y1ldırım \& Erol 2013), of which 97 are endemic to the country.

According to Mathew (1982), C. pestalozzae Boissier $(1854$ : 13, 17) exists in two colour forms, white and a clear lavender-blue. The original collection (type locality) from Bolu has white flowers, and the blue form was not discovered until 1929. The lavender-blue form, more commonly encountered in cultivation, from unknown origin, has been called var. caeruleus (but this not a formally published name). During our field studies, the blue form was found in an isolated population. In this study, white and blue forms, based on our herbarium and field observations, are treated as distinct subspecies.

Specimens of the taxon described here have been collected several times by the first author since 2001 and observations made concerning population size and phenological features. The specimens were compared with similar material at ISTE, ISTF, $\mathrm{K}$ and E. The measurements, colours and other details given in the description are based on both herbarium and living material. Morphological data were obtained from 70 individuals in total. The illustrations of the new subspecies were made from living material using Adobe Photoshop CS4.

Karyological observations were made on mitotic metaphase cells of root-tips obtained from corms that were collected in the type locality and around İstanbul. Root tips were pretreated in $\alpha$-monobromonaphthalene at $4{ }^{\circ} \mathrm{C}$ for 24 hours and fixed in Carnoy's solution (3:1 absolute ethanol: glacial acetic acid) for a minimum of 1 hour. The root tips were hydrolyzed for 12 minutes in $1 \mathrm{~N} \mathrm{HCI}$ at $60^{\circ} \mathrm{C}$, stained in Feulgen solution and squashed in aceto-orcein. Metaphases were observed using an Olympus BX53 light microscope and photographs were taken with the same. Also measurements of somatic chromosomes were made with the program CAMERAM, they were calculated with formula of the relative variation in chromosome length $\left(\mathrm{CV}_{\mathrm{CL}}\right)$ and mean centromeric asymmetry $\left(\mathrm{M}_{\mathrm{CA}}\right)$ in Zuo \& Yuan (2011) and Peruzzi \& Eroğlu (2013). Chromosomes were classified according to the nomenclature of Levan et al. (1964). 
Indeed, this feature is not detectable in the figures published by this author (Kandemir 2009, Fig. 4a; 2011, Fig. 11). On the other hand, distinct ribs were observed by us in cross sections of the leaf samples of $C$. pestalozzae that were collected around İstanbul. The type specimen of $C$. pestalozzae was collected by Pestalozza from the district of Bolu but without precise details. This species has not been re-collected from the type locality. Crocus pestalozzae subsp. pestalozzae is now known only from Kırklareli, İstanbul and Kocaeli Provinces (Fig. 2).

\section{Acknowledgements}

We wish to thank Brian Mathew and an anonymous reviewer for their constructive comments on the manuscript. Our thanks also to Tuna Ekim, Adil Güner and Margaret Johnson, for their scientific advice and Research Fund of Istanbul Univ. for financial support.

\section{References}

Boissier, E. (1854) Diagnoses plantarum orientalium novarum 1(13). Leipzig, $74 \mathrm{pp.}$

Brighton, A.C., Mathew, B. \& Marchant, C.J. (1973) Chromosome counts in the genus Crocus (Iridaceae). Kew Bulletin: $451-464$. http://dx.doi.org/10.2307/4108890

Candan, F. \& Özhatay, N. (2013) Crocus chrysanthus s. lato (Iridaceae) in Turkey. Annales Botanici Fennici 50: 423-430. http://dx.doi.org/10.5735/085.050.0610

Erol, O., Can, L. \& Ş1k, L. (2012) Crocus demirizianus sp. nov. from northwestern Turkey. Nordic Journal of Botany 30: 665-667. http://dx.doi.org/10.1111/j.1756-1051.2012.01684.x

Gay, J. (1831) Nouvelles espéces de Crocus. Bulletin des Sciences Naturelles et de Geologie 25: 319-321.

Harpke, D., Meng, S., Rutten, T., Kerndorff, H. \& Blattner, F.R. (2013) Phylogeny of Crocus (Iridaceae) based on one chloroplast and two nuclear loci: ancient hybridization and chromosome number evolution. Molecular Phylogenetics and Evolution 66: 617-627. http://dx.doi.org/10.1016/j.ympev.2012.10.007

IUCN Species Survival Commission. (2001) IUCN Red List Categories and Criteria. Approved by the 51st Meeting of the IUCN Council, Version 3.1. Gland: IUCN.

Kandemir, N. (2009) Morphology, anatomy and ecology of critically endangered endemic Crocus pestalozzae Boiss. (Iridaceae) in northwest Turkey. Bangladesh Journal of Botany 38: 127-132. http://dx.doi.org/10.3329/bjb.v38i2.5136

Kandemir, N. (2011) Comparative leaf anatomy of some endemic Crocus L. taxa from Turkey. Bangladesh Journal of Botany 40: 155162. http://dx.doi.org/10.3329/bjb.v40i2.9771

Kerndorff, H., Pasche, E., Blattner, F.R. \& Harpke, D. (2013a) Fourteen new species of Crocus (Liliiflorae, Iridaceae) from west, southwest and south-central Turkey. Stapfia 99: 145-158.

Kerndorff, H., Pasche, E., Blattner, F.R. \& Harpke, D. (2013b) A new species of Crocus (Liliiflorae, Iridaceae) from Turkey. Stapfia 99: $141-144$.

Kerndorff, H., Pasche, E., Blattner, F.R. \& Harpke, D. (2013c) Crocus biflorus Miller (Liliiflorae, Iridaceae) in Anatolia - Part IV. Stapfia 99: 159-186.

Levan, A., Fredga, K. \& Sandberg, A.A. (1964) Nomenclature for centromeric position on chromosomes. Hereditas 52: $201-220$. http://dx.doi.org/10.1111/j.1601-5223.1964.tb01953.x

Linnaeus, C. (1753) Species plantarum. Laurentii, Stockholm. 560 pp.

Mathew, B. (1982) The Crocus. A revision of the genus Crocus. Batsford, London, 127 pp.

Mathew, B. (1984) Crocus L. In: Davis, P.H. (Ed.) Flora of Turkey and the east Aegean islands 8. Edinburgh University Press, Edinburgh, pp. 413-438.

Mathew, B. (1988) Crocus L. In: Davis, P.H. (Ed.) Flora of Turkey and the east Aegean islands 10, suppl. Edinburgh University Press, Edinburgh, p. 288.

Mathew, B. (2000) Crocus L. In: Güner, A., Özhatay, N., Ekim, T. \& Canbaşer, K.H. (Eds.) Flora of Turkey and the east Aegean islands 11, suppl. Edinburgh University Press, Edinburgh, pp. 271-274.

Peruzzi, L. \& Carta, A. (2011) Crocus ilvensis sp. nov. (sect. Crocus, Iridaceae), endemic to Elba Island (Tuscan Archipelago, Italy). Nordic Journal of Botany 29: 6-13. 
http://dx.doi.org/10.1111/j.1756-1051.2010.01023.x

Peruzzi, L., Carta, A. \& Garbari, F. (2013) Lectotypification of the name Crocus sativus var. vernus L. (Iridaceae) and its consequences within the ser. Verni. Taxon 62: 1037-1040.

http://dx.doi.org/10.12705/625.7

Peruzzi, L. \& Eroğlu, H.E. (2013). Karyotype asymmetry: again, how to measure and what to measure? Comparative Cytogenetics 7: 1-9. http://dx.doi.org/10.3897/compcytogen.v7i1.4431

Ruksans, J. (2013) Seven new crocuses from the Balkans and Turkey. The alpine garden society 1-27.

Yıldırım, H. \& Erol, O. (2013) Crocus yakarianus sp. nov. from eastern Turkey. Nordic Journal of Botany 31: 426-429. http://dx.doi.org/10.1111/j.1756-1051.2012.01786.x

Yüzbaşığlu, S. (2012) Crocus L. In: Güner, A., Aslan, S., Ekim, T., Vural, M. \& Babaç, M.T. (Eds.) Türkiye Bitkileri Listesi (Damarlı Bitkiler). Nezahat Gökyiğit Botanik Bahçesi ve Flora Araştırmaları Derneği Yayını, İstanbul, pp. 530-535.

Zuo, L. \& Yuan, Q. (2011) The difference between the heterogeneity of the centromeric index and intrachromosomal asymmetry. Plant Systematics and Evolution 297: 141-145.

http://dx.doi.org/10.1007/s00606-011-0528-x 